\title{
Botanical Relics of a Lost Landscape: herborising 'upon the Cliffs about the Pharos' in Genoa, March 1664
}

\author{
Raffaella Bruzzone $^{\mathrm{a}}$, Charles Watkins ${ }^{\mathrm{b}}$, Ross Balzaretti ${ }^{\mathrm{c}}$, Carlo Montanari ${ }^{\mathrm{d}}$ \\ ${ }^{a}$ Marie Curie Intra-European Fellowship (CIRCKNOW - The circulation of naturalistic knowledge in Modern Europe (1500- \\ 1850): a micro-analytical perspective), School of Geography and Department of History (University of Nottingham, UK); ${ }^{\text {b }}$ \\ School of Geography (University of Nottingham, UK) ${ }^{\mathrm{c}}$ Department of History (University of Nottingham, UK); ${ }^{\mathrm{d}}$ DISTAV \\ (Dipartimento di Scienze della Terra, dell'Ambiente e della Vita, University of Genoa, IT)
}

Keywords: Urban Biodiversity, John Ray, Francis Willughby, Genoa, landscape change

\begin{abstract}
This paper uses approaches derived from historical ecology to show how knowledge can be gained about the historical and cultural value of neglected and overlooked urban landscapes. We study a particular site, the rocks on which Genoa's lighthouse is built, and consider the possibility of the long term survival of individual plant species and some implications for contemporary landscape conservation and planning. We examine topographical representations of the area over the last 500 years to understand the landscape context of the lighthouse. We then analyse the records of plants collected and listed by two leading English naturalists of the seventeenth century, John Ray and Francis Willughby. We demonstrate how the plants were identified and documented and the relationship between manuscript and published sources. We then survey the current vegetation to establish whether any species identified in 1664 still grow at the site. This exploration of botanical ancestry at a local scale makes it possible to demonstrate the cultural-historical value of the lighthouse rocks and their vegetation which should be considered as part of the cultural heritage of the city of Genoa.
\end{abstract}

\section{Introduction}

This paper is about the landscape history, ecology and geography of the rocky outcrop on which Genoa lighthouse is built. The English naturalists John Ray (1627-1705) and Francis Willughby (1635-1672) collected plants around the lighthouse at Easter 1664 (Welch, 1972; Boulger, 2004; Mandelbrote, 2004; Greengrass et al. 2016). We analyse their records and compare them to a present day survey to assess whether any of the plants they recorded exist at the place today. The paper makes a contribution to the debate about the role of green spaces in urban planning and in particular the extent to which biodiversity associated with particular places can be understood (Ives and Kelly, 2015). There is an enormous literature on the history of urban landscapes including their street trees, arboreta and gardens (Elliott et al. 2011; Pellegrini and Baudry 2014). Recently there has been an upsurge of interest in the relationship and interconnections between plants and people (Head et al. 2014). This paper adds to this literature by considering the role of historical plant collecting and topographical representations in landscape research (Piana et al. 2012). It also explores the heritage value of small urban sites which have been largely forgotten and considered as blank spaces by urban planners (Unt et al. 2014). It shows that, by using approaches derived from microhistory (Ginzburg, 1993; Balzaretti et al. 2004; Raggio, 2013) and historical ecology (Moreno, 1990; Grove and Rackham, 2003; Cevasco, 2007) cultural value can be derived and ascribed to places which have hitherto been overlooked.

The intellectual importance of British visitors and collectors in Italy from the seventeenth century onwards is a fruitful and important area of research (Black, 2003; Chaney, 1998; Chaney and 
Wilks, 2014; Chard, 1999). Genoa was one of the main stop-overs in northern Italy on the route down to Tuscany and Florence (Sweet, 2012 p. 75). The implications of the Grand Tour for art and architectural history are enormous not only in the spread of ideas, but also in the establishment of museums and the encouragement of conservation and tourism in contemporary Italy. But visitors were also interested in the natural world. In this paper we consider the collection of plants by two of the leading English naturalists of the seventeenth century. We consider how they collected and identified the plants in the field and how the dried specimens they took back to England were later conserved and used for further analysis. We consider the long term survival of species at this site of different plant species and the implications for contemporary urban conservation. .

\section{Genoa Lighthouse}

By the fourteenth century Genoa had a population of over 100,000 and had become the leading port, trading and banking centre of the Western Mediterranean. The population within the city boundaries grew to 688,447 by the mid twentieth century (1951 census) but had fallen to 587,469 by 2015 (Arvati, 2007, p. 394; Pesce et al., 2015, p. 17). The city developed next to its large natural harbour on the narrow coastal plain of Liguria (Poleggi, 1982). The lighthouse has been on the promontory on the western side of the harbour below St Benigno Hill since at least 1128. The first illumination was the burning of heather ('brugo' in dialect) or broom branches on top of a tower; the first olive-oil lantern was in 1326 (Praga, 1998). The Lighthouse was completely rebuilt in 1543 financed by the Banco di San Giorgio (Poleggi \& Cevini 1981, p. 84). During the seventeenthcentury St Beningo Monastery and the Lighthouse were included in the new city walls (Mura Nuove) but following the Napoleonic takeover in 1798 the monastery was abolished. In the nineteenth and twentieth centuries most of the hill was quarried away during the rapid industrialisation of the city.

We examined depictions and descriptions the city over the last 500 years to establish how the lighthouse and its immediate context were represented. Early birds-eye views of the city (Poleggi, 1976; Poleggi \& Cevini, 1981; Poleggi, 1982) were mainly by cartographer-painters such as Jan Massys, Venus with the view of Genoa, 1561 (Galassi, 2015) ${ }^{1}$ and Cristoforo de' Grassi dated 1597 (Poleggi \& Cevini, 1981, p. 82) where St. Benigno hill is clearly drawn. Travellers to Genoa in the seventeenth century frequently described the Lighthouse and climbed the hill of St Benigno to look across the harbour to the city. Carignano to the east was the best place to view the Lighthouse on its rocky promontory (Stoye, 1989, pp. 124-5). Francesco Scotto's guidebook (Scotto, 1615) first published in 1600 includes a view of Genoa which depicts the Lighthouse with rocks and walls, but hardly any signs of vegetation (Figure 1$)^{2}$ 


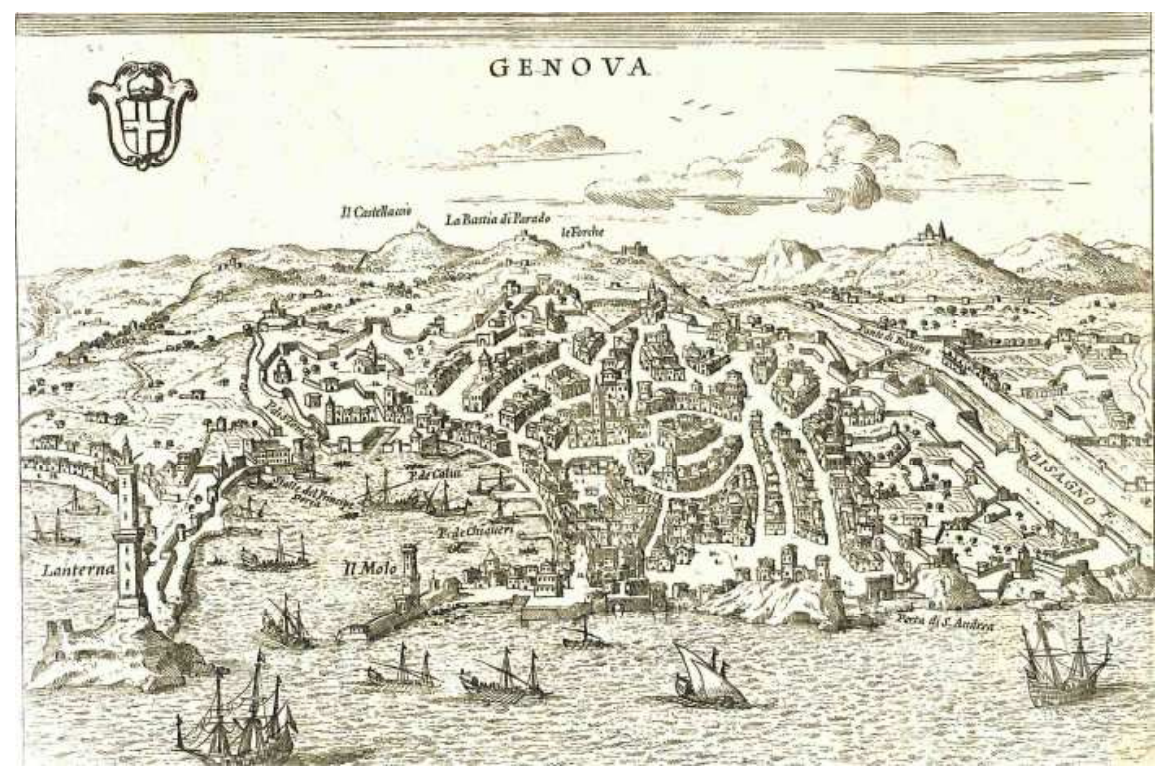

Figure 1 View of Genoa in F. Scoto Itinerario d'Italia (Padua, 1659) @ R. Bruzzone

Two English authors described the Lighthouse in the mid seventeenth century. John Evelyn (16201706) noted on 16 October 1644: 'we got to Anker under the Pharos or Watch-towre erected on a high rock, at the mouth of the Mole of Genoa [...]' (De Beer, 1959, p. 96). Richard Lassels in his Voyage of Italy (1670) described the site and history of the Pharos: '...At one end of this Mola stands a Pharos upon a little rock, with a Lantern upon it, to give notice, by known signes, what Ships, how many, and from what side they Come: or else to guide their own Ships home safely in the night.' (Lassels, 1670, p. 84). A drawing of the landscape immediately around the Lighthouse dated 26 June 1699 (Figure 2) depicts the area around it with fluid lines of ink similar to the ones around the monastery and the villas on the promontory of St. Benigno. ${ }^{3}$ In 1754 George Keate (1729-1797) drew a view of the Lighthouse from the west which shows the Lighthouse on its rocky base (Figure 3). The first of these drawing emphasises the semi-rural context of the lighthouse and both hint at the vegetation growing on the lighthouse rock.

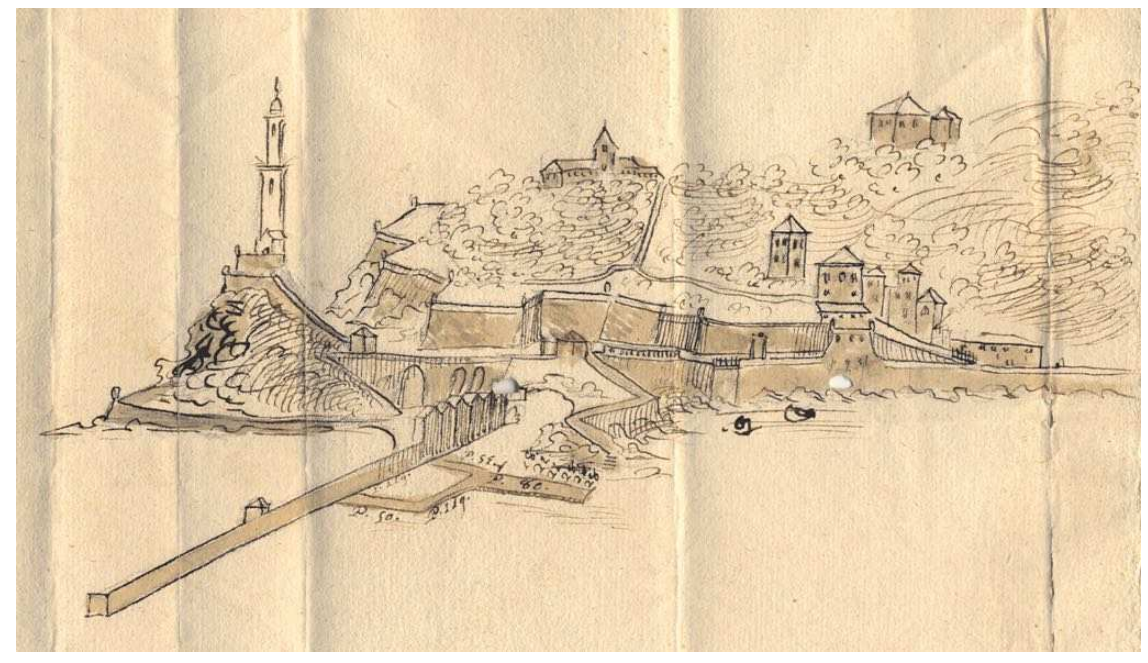

Figure 2 Sketch of the area around the Lighthouse related to the construction of the new dry dock in the new pier dated 26 June 1699, Padri del Comune, filza 231-96. (C) Archivio Storico del Comune di Genova. 


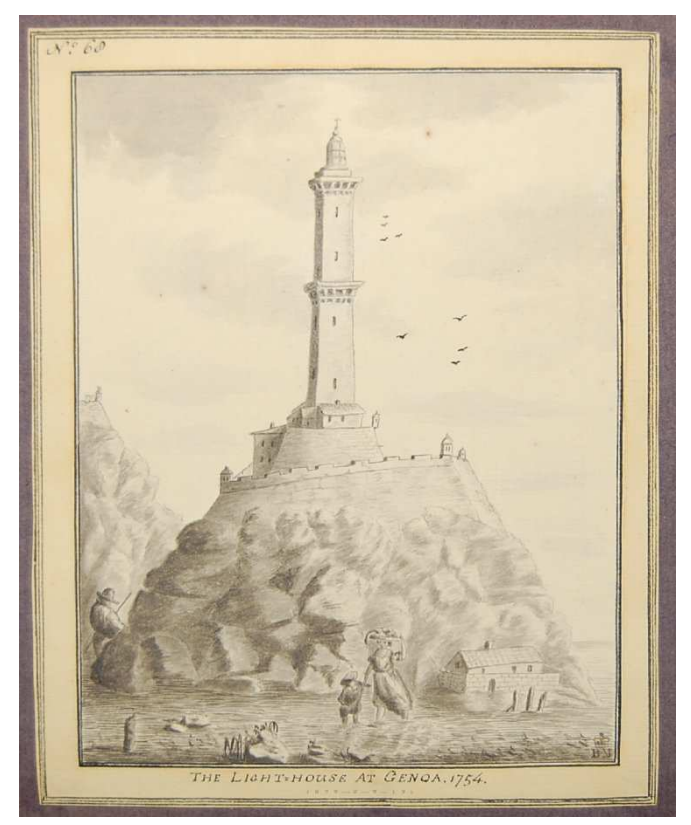

Figure 3 “The Lighthouse at Genoa. 1754”, George Keate (1729-1797) () Trustees of the British Museum.

Two early nineteenth century views show vegetation adjoining the lighthouse. That by Domenico Del Pino (1793-1851) shows the Monastery above the lighthouse surrounded by agricultural terraces and cultivated land (Figure 4). One can just detect a patch of vegetation on the lighthouse rock itself. That by Luigi Garibbo (1784-1869) dated 1812-14 (Figure 5) shows the view to the west taken from the Lighthouse rock. Next to the person sitting on the rocks there is shrubby vegetation; behind the guard and the boy pointing there is a shrub which is too indistinct to identify; the walls of the promenade are possibly covered by Capparis spinosa L. (caper). The rocks above, underneath the fortification, are partially covered in green, unidentified vegetation. ${ }^{4}$

The lighthouse is one of the most prominent structures in Genoa and so figures in many drawings and descriptions. This analysis of the representations of the Lighthouse through time shows that there is a strong possibility for continuity of vegetation on the rocks below the Lighthouse between 1600 and the early nineteenth-century. However we can only really guess about the species that grew there. In the next section we consider evidence for the existence of particular species taken from botanical surveys.

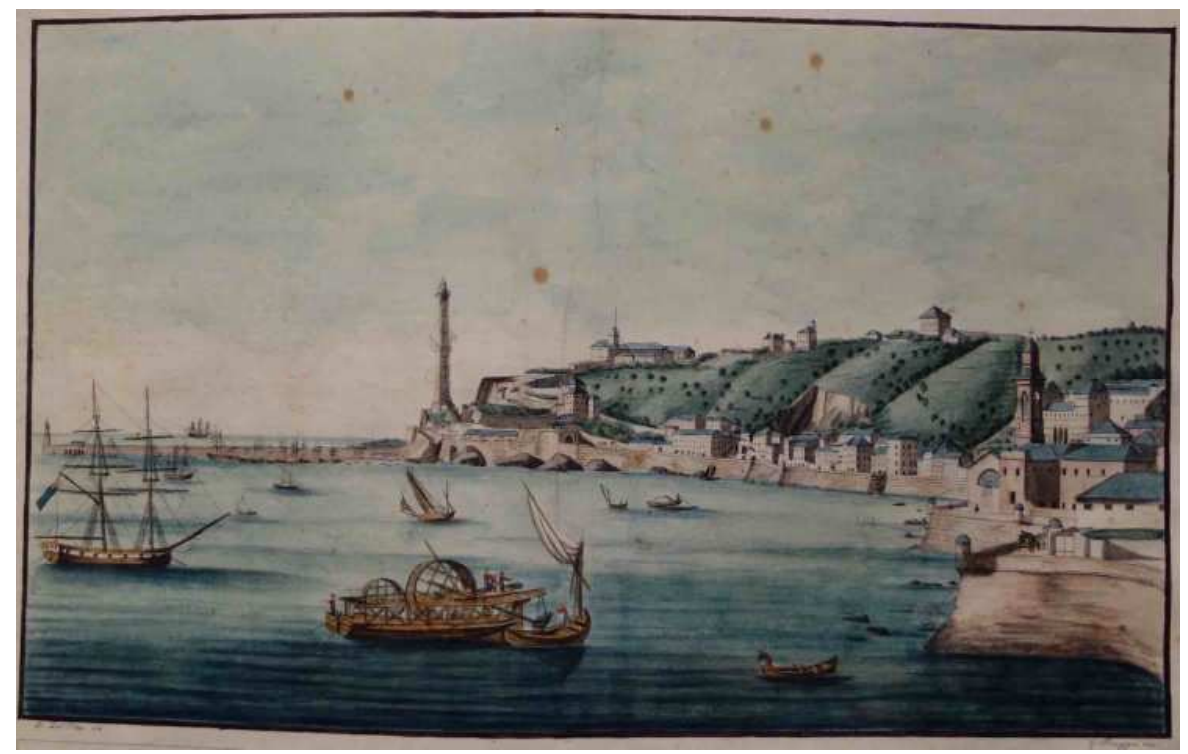


Figure 4 "Veduta del porto di Genova verso la Lanterna, dai pressi di San Teodoro", Domenico Del Pino (first half of nineteenth-century) (C) Collezione Topografica e Cartografica, Genoa.

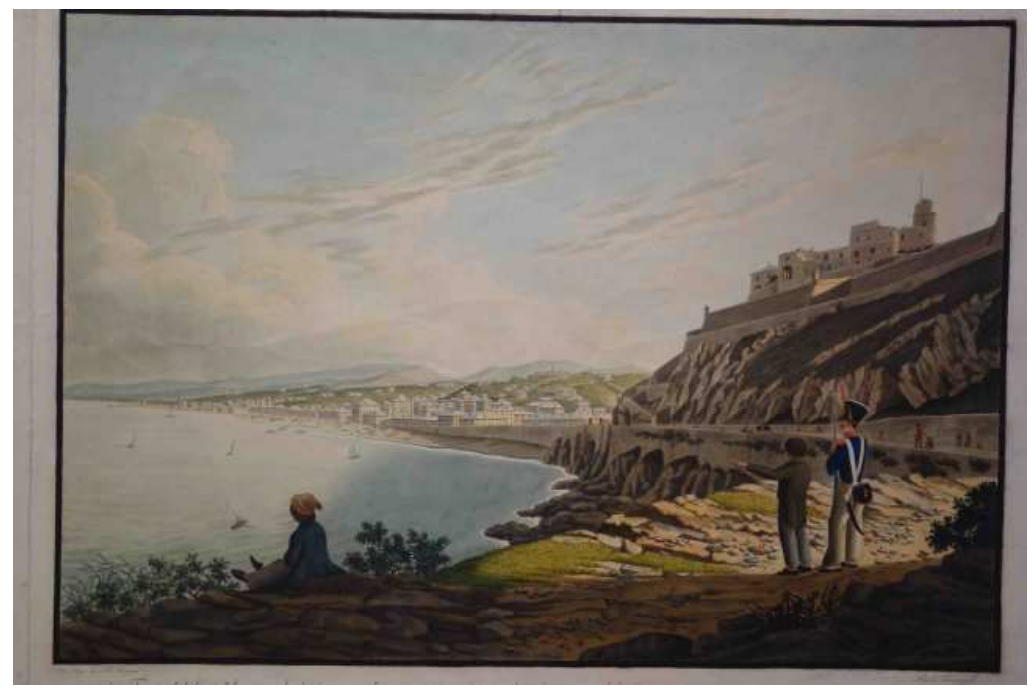

Figure 5 "Veduta del sobborgo di Sampiardarena al ponente della città di Genova presa dallo scoglio della Lanterna", Luigi Garibbo (1812-14) @ Collezione Topografica e Cartografica, Genoa.

\section{Ray and Willughby collecting plants at Genoa, March 1664}

John Ray (1627-1705) and Francis Willughby (1635-1672) were early members of the Royal Society and together collected and catalogued many plant and animal species. Ray entered Trinity College Cambridge in 1644 and gained a fellowship in 1649 (Oswald \& Preston 2011, pp. 4-5). He is 'remembered as Linnaeus's predecessor in the science of taxonomy, but he had not Linnaeus's gift for publicity' (Rackham, 2011, p. vii). He met Francis Willughby at Trinity College and they collaborated on botanical trips, first around Cambridgeshire for Ray's Catalogus plantarum circa Cantambrigiam nascentium (1660) and made extensive travels around England and Wales collecting botanical specimens. They toured Europe 1663-1666 with Philip Skippon and Nathaniel Bacon, both Ray's pupils (Hunter, 2014; Greengrass et al., 2016). They arrived in Italy in October 1663 and Ray stayed there until March $1665 .{ }^{5}$ He published his own account of the journey as Observations Topographical, Moral, \& Physiological Made in a Journey Through part of the LowCountries, Germany, Italy, and France: with A Catalogue of Plants not Native of England, found Spontaneously growing in those Parts, and their Virtues (Ray, 1673). On their journey they collected and purchased many items of natural history interest including drawings and prints of birds, fish and plants and a volume of dried plants from Padua. They collected many specimens of plants in the field and dried them so that they could be identified and taken home to England. One of their known collecting points was on the rocks below the Lighthouse at Genoa, and in this section we examine whether we can identify the plants collected there.

Descriptions of their time at Genoa are provided by John Ray and Philip Skippon. The group arrived in Genoa on 20 March 1664, travelling from Asti in Piedmont across the Apennines through Novi and staying overnight in the small hilltop town of Voltaggio. Ray's account of Genoa is similar to others in recording the sumptuous architecture of Strada Nuova (today Via Garibaldi) with its string of palaces built above the medieval city. He quotes the proverb 'montagne senza alberi, mare senza pesce, huomini senza fede \& donne senza vergogna' that is, 'Mountains without trees, a Sea without fish, Men without faith, and Women without shame' (Ray, 1673, p. 253). ${ }^{6}$ Philip Skippon's (1732) account of the journey provides more detail: 'many chestnut trees grow on the hills, and near Genoa are large olive grounds'. After they 'left Voltaggio we met and overtook 
about 500 or 600 mules and asses laden' and also gardens full of orange trees just before entering 'the outwall of Genoa nigh the Pharos, and rode by the haven's side, then came thro' a gate where a guard of soldiers was kept'. Skippon's account confirms that the Pharos was the first place they saw in Genoa and he then gives detailed descriptions of the churches, the palaces in Strada Nuova, the Hospital and the Duke's palace. On Holy Thursday 1664 they attended the famous noon procession 'which lasted till two hours in the night' and which was probably one of the reasons they chose to be in Genoa over Easter. ${ }^{7}$ They stayed in Genoa until 2 April and then sailed in a felucca on to Tuscany describing the shore of the 'Riviera di Genoa' as being 'hilly, and full of pleasant houses'.

The identification of the plants they collected at Genoa is not a simple task. First we needed to establish what had happened to the collected plants. Unfortunately not all the specimens survive and most of those that do seem to be from Sicily, where they later spent two months collecting plants. ${ }^{8}$ Much of their collection of dried specimens is now found within the pages of a copy of John Ray's Historia Plantarum printed in 1686/8 held at the University of Nottingham. This is in five volumes and dried plants are mounted next to the corresponding description. ${ }^{9}$ The production and preservation of this collection has a complicated history and it is likely that it was undertaken by Francis Willughby's children Thomas and Cassandra. The specimens collected from Italy are mixed up with plants collected in many other places including some from the Botanical Garden in Padua. Some dried specimens collected in Europe are now part of Ray's herbarium in the Sloane Collection at the Natural History Museum (London), in nine volumes of loose sheets known as Hortus Siccus Rayanus. ${ }^{10}$ These plant specimens are also mixed from British and European travels and are mainly labelled with Ray's handwriting but also Skippon's. The herbarium has been used and modified through time and many of the specimens have been cut out as we can see in the example of Herba Paris (Figure 6). ${ }^{11}$

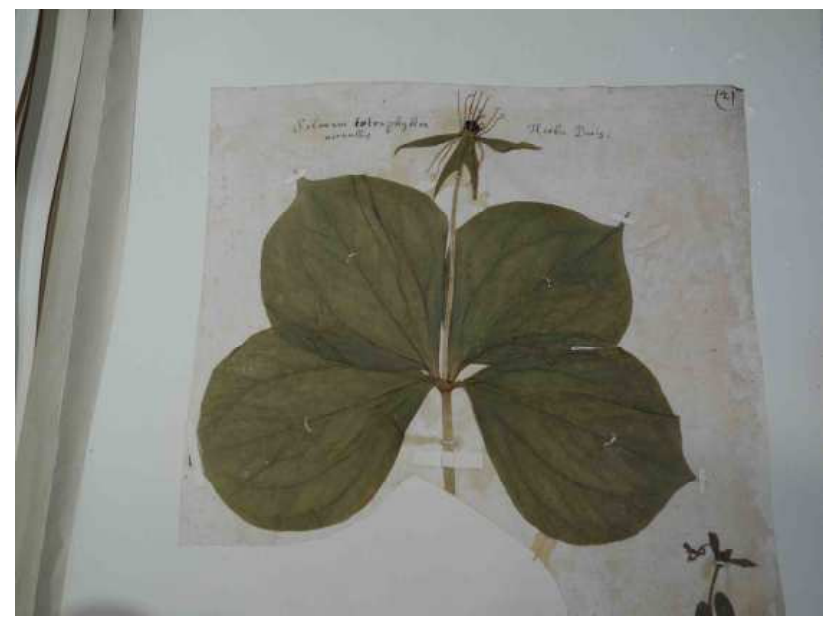

Figure 6 Herba Paris, Hortus Siccus Rayanus, Sloane Collection ( Natural History Museum, London.

When John Ray and Willughby collected plants along the route of their journey, Ray wrote a list of the names of the plants identified on the first and last blank pages of his copy of the catalogue of the Botanical Garden in Padua printed in 1662 (Greengrass et al., 2016). ${ }^{12}$ This list demonstrates that they collected a total of 14 specimens around the Lighthouse 'upon the Cliffs about the Pharos'. ${ }^{13}$ Ray used this pocket book as a notebook but did not link his manuscript entries with plants listed in his published text (Ray 1673). A transcription of the manuscript list is given in Table 1. The manuscript list indicates that they did not make a complete list of all plants on the rock, but only those that were new to them or interested them. 
Upon the rockes near the Pharos by $y^{e}$ port at Genoua

2. Trifolium bituminosum.

3. Jacobaea marina sive Cineraria.

4. Conyza odorata Monspeliaca.

5. Alaternus.

6. Carduus lacteus peregrinus.

7. Thymus moscatus.

8. Geraniū Althaeae folio.

9. Thlaspi incarnū marinū flore albo.

10 Lotus an Cytisus villosus?

11 Dorycniū Monspeliens:

12 Smilax aspera.

On the rockes on the east side of $y^{e}$ town besides the former

13. Genista hispanica.

14. Adianthum nigrum.

15. Hyoscyamus 2 Tab. in Icon.

The Thlaspi incarnū is somewh $h^{t}$ like Leucoium luteum but much lesse. It may be thus described. Ex rad. Alba, simplici lignosa, perenni, paucis fibris capillata ramulos emittit pluros, imbollos, humi procumbentos, striates quos folias occupant alternatim nullo ordine posita: Flores summitatibus ramulorum albi, quadrifoli medio coloris obscurioris, in universe flore Narturtij aquatici simillimi ? Vasculū seminale parvū compressum, in [...] emitato acutum, due vel forte tria so[...] comple[...]. Saporem habet acrem [...]poliqua hujus generis, odorem nullū.

Haec species Hyoscyami quam in muris crescentem vidimus \& in rupibus circa Genuam a vulgari differt quod folia habeat viridiora, breviora, rotundiora, minùs laciniata; florem minorem, totum luteum, cum fundus floris in vulgari niger sit, \& flos ipso albidior. In universum planta hac propiùs accedit Hyoscyamū luteum Peruvianū Tobacco Anglicum dictum quàm Hyosc. Vulgari.

The last part of the note can be translated as: 'This species of Henbane which we saw growing on walls and on rocks around Genoa differs from the common one because it has greener, shorter, rounder, less divided leaves and a smaller, wholly yellow flower, since the eye of the flower in the common species is black and its flower whiter than in this plant itself. Altogether this plant comes closer to the Peruvian yellow Henbane called English Tobacco than to the common Henbane.' This indicates Ray's working method of identification in the field and his interest in recognising new species. ${ }^{14}$

A comparison of this list with the dried specimens held in Nottingham and London showed that only two can be identified as those collected around the Lighthouse: Jacobaa marina sive Cineraria in rupibus maritimis ${ }^{15}$ and Smilax aspera. ${ }^{16}$ Further analysis, however, shows that in Ray (1673), the published list, we find the same list but the plants have been carefully identified ${ }^{17}$ and cross referenced with botanical books which were in Willughby's and Ray's libraries. It is possible to check this thanks to a manuscript list of books of the Willughby family ${ }^{18}$ and the auction catalogue of Ray's library which was sold in 1708. Both men had rich collections of botanical books, such as the Historia Plantarum by J. Bauhin, and other works by Parkinson, Brunfels, Fuchs, Mattioli, Morrison and Petiver. ${ }^{19}$ In Ray (1673) plants are identified and cross referenced to sources by the following abbreviations: C.B. (Caspar Bauhin), J.B. (Jean Bauhin), Ger. (John Gerarde), Park. (John Parkinson) ${ }^{20}$ In the manuscript notebook the only abbreviated source reference found is Tab. next to henbane (Hyoscyamus albus L.), which stands for Tabernaemontanus, referring to the Eicones Plantarum (1590), a catalogue of plants they could easily carry when travelling. ${ }^{21}$ This book consists of botanical iconographies reproduced from other authors including Bock, Fuchs, Dodoens, Mattioli, de l'Ecluse and de l'Obel (Arber, 1912, pp. 678). This analysis shows the complex background to the identification of plants collected in 1664 
with some being identified in the field making use of portable published identification manuals, and others being identified on their return to England when they had access to their libraries. They only collected those plants that were new to them, or difficult to identify, and were useful for them as additions to the list of plants 'not native of England' later published by Ray (1673).

\section{Evidence for survival of species from plant collecting at the Lighthouse in the nineteenth century and today}

What evidence do we have that there is continuity in the species found on the Lighthouse rock in later years? The first evidence of botanical collecting at the Lighthouse after 1664 is that done by Antonio Bertoloni, who compiled a Genoese flora and collected at least four plants 'sub la Lanterna' (Bertoloni, 1804). ${ }^{22}$ One of these is Cineraria maritima (Jacobaea maritima (L.) Pelser \& Meijden). ${ }^{23}$ The volume is enriched with botanical watercolours probably made by the author himself or by a collaborator (Figure 7). An entry of Matthiola incana around 'alla Cava' has been found in the notes by Otto Penzig on De Notaris' work (1844, p. 43). The same plants have been found in many records of the historical herbal held at the Museo Civico di Storia Naturale "Giacomo Doria" (Natural History Museum of Genoa) and the Polo Botanico Hanbury (Botanical Garden, Genoa (Tab. 1), with placenames which indicate the area around the Lighthouse and the St. Benigno Hill such as 'La Cava' (the quarry), 'Il Tunnel', 'Galleria S. Benigno' (the St. Benigno tunnel), 'sotto le Mura della Cava' (underneath the quarry's walls), 'Genuae in moeniis maritimis prope la Cava' (in Genoa on maritime walls around the quarry, Figure 8). ${ }^{24}$ Overall then, we have little botanical evidence from nineteenth-century sources but there is some evidence of continuity in a small number of species.

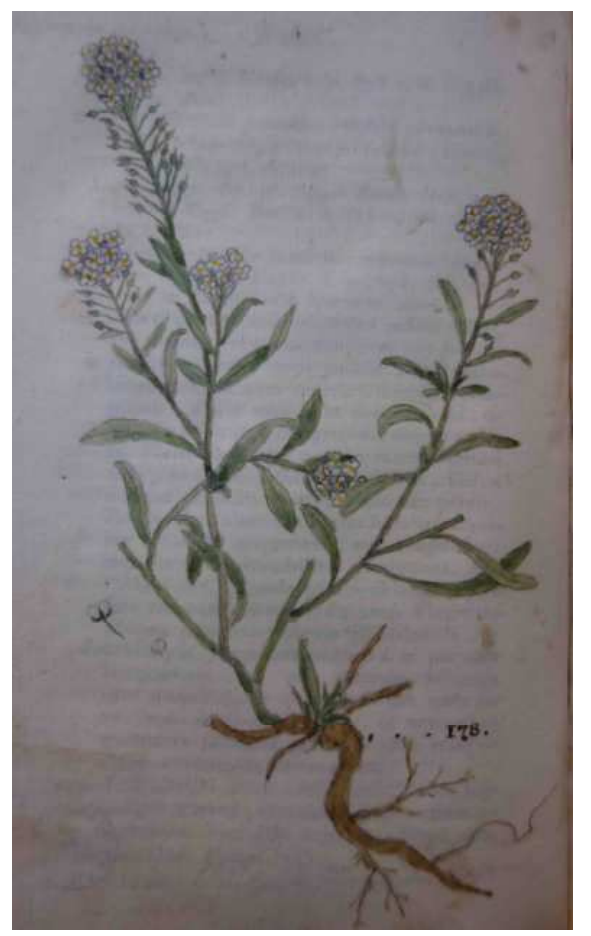

Figure. 7 178. Alyssum maritimum [...] In moeniis maritimis Genuae. Floret tota hyeme. Peren. alla Cava @ Biblioteca della Scuola di Scienze MFN - Sede BTM, University of Genoa. 


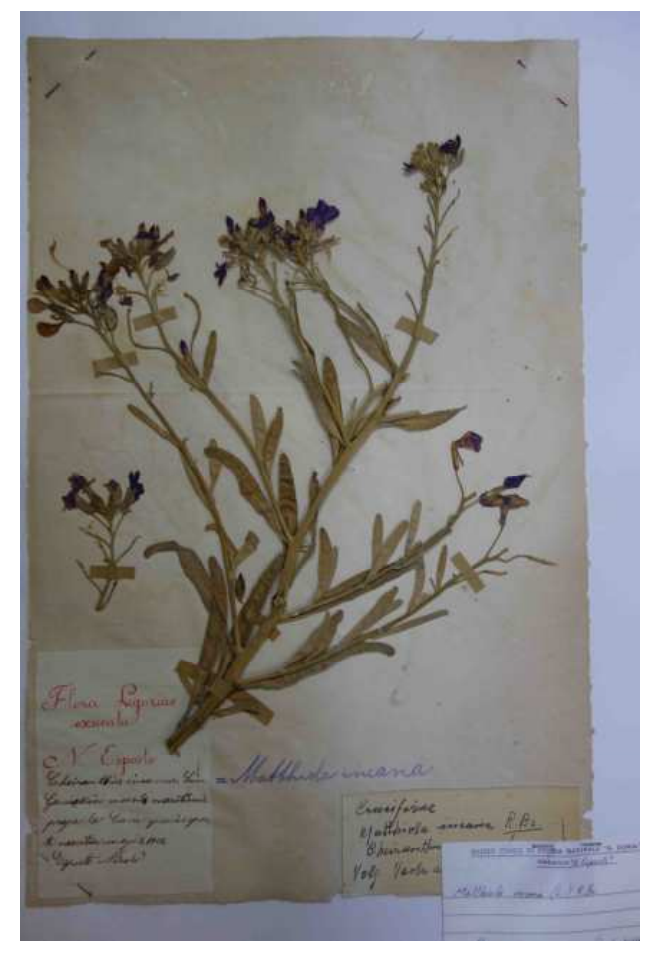

Figure. 8 Matthiola incana (L.) R. Br., 'Flora Liguriae exsicata. N. Esposto. Cheiranthus incanus. Lin. Genuae in moeniis maritimis prope la Cava species sponte nascitur majo.9.1902. Esposto Nicolò’ (C) Museo Civico di Storia Naturale “Giacomo Doria”, Genoa.

Although most of the hillside and the surrounding semi-rural areas were removed during the twentieth century by quarrying and road and factory construction, there is still some vegetation immediately around the Lighthouse. In order to ascertain whether any of the species listed by Ray (1673) were still found on the rock we carried out five surveys between September 2014 and September 2015 at various times of the year and it was possible to identify nine species of plant on the rocks and walls that had been noted by Ray (Table 2) and an additional 28 species were also identified. ${ }^{25}$ The survey was undertaken by following paths and access points on the Lighthouse rock which were all accessible to members of the public visiting the Lighthouse. A few areas were impossible to survey because they were dangerous to reach or covered by aggressive species like Ipomoea purpurea (L.) Roth and Rubus ulmifolius Schott (blackberry).

A comparison was made between the results of our field survey and Ray and Willughby's lists from the notebook at Chelsea Physic Garden and the botanical list in Ray's Observations (1673). At least nine plants from the 1664 herborising were also found today, and these were identified with their current scientific name (Table 2). The identification of the plants was carried out through John Ray's Historia Plantarum (Ray, 1686, 1688, 1704) and other works they could have used at the time (Bauhin, 1650; Bauhin, 1658; Gerarde, 1636; Parkinson, 1640) but also through the Linnaean system (Jarvis, 2007; Petermann, 1840; Richter 1840) and the historical approach was privileged. In the case of Genista hispanica, Ray must have seen Spartium junceum (whose common name is also Spanish broom and we find it in Ray 1688, p. 1726). The relics of the plants collected by Ray and Willughby found on the rocks and on ancient walls around the Lighthouse were: Bituminaria bituminosa (L.) C.H. Stirt., Hyoscyamus albus L., Jacobaea maritima (L.) Pelser \& Meijden, Lobularia maritima (L.) Desv., Smilax aspera L., Thymus vulgaris L., Erodium malacoides L., Matthiola incana (L.) R. Br. (Figure. 10) and Inula viscosa (L.) Aiton. The plants that no longer survive were probably on the area that has been quarried away or have replaced by invasive species. 
We presented some of these research results at a public engagement event organised together with the association 'Giovani Urbanisti Fondazione Mario e Giorgio Labò', a group of young Genoese urban, land and environmental planners. Initial discussions with this group showed that members had no prior knowledge of the history of plant collecting at the site. We also, as part of the CIRCKNOW project, organised an educational activity for children in the context of the European Researchers' Night in September 2015 about the botanical history around the Lighthouse, the making of herbaria, and the history of the identification and naming of plants. We also provided a guided walk around parts of the Lighthouse rock. The Giovani Urbanisti were interested to discover the botanical history of the rock and a display panel about the importance of the historical-botanical heritage of the lighthouse rock was displayed during this event which is now part of the permanent exhibition at the Lighthouse. The research results provide evidence which allows the Giovani Urbanisti to increase the interest and the perception of this symbol of the city and its surrounding semi-natural heritage. We hope that through guided tours and other activities it will be possible to encourage the local public and tourists to take greater interest in the landscape and botanical heritage of the city (Caneva, 2005, pp. 293-297).

\section{Conclusion}

There has recently been a call for more studies of the subtle interconnections between plants and animals at different sites and places (Head et al., 2014). This paper makes a contribution to this debate by considering the history of plants growing in urban rocks and walls which are often seen as ephemeral (Francis, 2011). We show that such places may have a botanical history which is worth exploring. The botanical history of such small, forgotten sites can be examined to assist conservation policies and to ensure that species seen as ephemeral and unimportant are accorded greater value. The paper demonstrates that the analysis of topographical art can be a useful way of identifying potential sites with a long vegetation history within urban areas (Piana et al., 2012).

The paper also shows that by reconnecting documents scattered in different archives and libraries in London, Nottingham and Genoa with the place to which they relate it is possible to give greater value both to the archives and the place itself. By using a micro analytical approach at a local scale it is possible to ascribe new values and meanings to the area around the lighthouse, an area that had become 'lost' over the centuries. While the plants found at the site today are few, their botanical ancestry can be explored through the use of the records of past collecting (Caneva, 2004).

More research is needed on the potential value of such sites for increased public engagement and understanding of botanical and ecological history by bringing the history of natural history out of museums and into the field. This paper has shown that it is possible by using contemporary botanical surveys and comparing these to a survey of the seventeenth century to establish long term continuity in the types of plant species growing in a place that became heavily urbanised in the nineteenth and twentieth centuries. Approaches derived from historical ecology, and more usually used in the study of rural habitats such as ancient woodlands and herb-rich meadows, can be useful for gaining knowledge about the historical and cultural value of urban landscapes which might otherwise be neglected and overlooked. We have demonstrated that the landscape around the Lighthouse and its rocks and the vegetation growing on them should be considered as part of the cultural heritage of the city of Genoa.

\section{Acknowledgments}

This research was funded by the European Commission under the FP7-PEOPLE-2013-IEF Marie Curie Intra-European Fellowship Programme. We would like to thank the following for advice and 
assistance: Christopher Preston; Dorothy Johnston and Linda Shaw, Manuscripts and Special Collections (University of Nottingham); Charlie Jarvis, Natural History Museum (London); Liz Thornton, Chelsea Physic Garden library (London); Elaine Charwat, Linnean Society library (London); Giuliano Doria and Maria Tavano, Museo Civico di Storia Naturale "Giacomo Doria" (Natural History Museum of Genoa); Giuseppina Barberis (University of Genoa); Enrico Isola, Archivio Storico del Comune di Genova; Patrizia Borghi, Collezione Topografica e Cartografica del Comune di Genova; Paola Caiffi and Maria Di Santo, Biblioteca della Scuola di Scienze MFN Sede BTM (University of Genoa). We would also like to thank the referees for their comments and helpful advice.

\section{Notes}

${ }^{1}$ M. C. Galassi (2015) supports the hypothesis of collaboration for the landscape in the background with Anton van den Wyngaerde, who in 1553 executed a large etching with a view of Genoa and its surroundings (View of Genoa, 1553. Stockholm, National Library of Sweden Maps and Pictures De la Gardie 64).

${ }^{2}$ Or Franesco Scoto or Franz Schott from Antwerp. There are two editions in the British Library (London) which include different views of Genoa. In the edition published in Vicenza (1615) it is simple and rough compared to the one published in Padova (1659), which is more detailed and refined. This is similar to an etching dated 1572-1576 by Franz Hogenberg, Genua Ligurum Domina [...] (Collezione Topografica e Cartografica del Comune di Genova, inv. 1956), part of the Civitates orbis terrarium (1572-1618).

${ }^{3}$ Archivio Storico del Comune di Genova, Padri del Comune, filza 231-96.

${ }^{4}$ L. Garibbo, Veduta del sobborgo di Sampiardarena al ponente della città di Genova presa dallo scoglio della Lanterna, 470x642 mm, etching and watercolour (Collezione Topografica e Cartografica, Genoa, n.inv. 1404). For details on Garibbo's paintings see the catalogue of the exhibition (Papone \& Serra, 2011).

${ }^{5}$ Passports from Whitehall on 10 April 1663, in the Nottingham University Library (from now on NUL) Mi 4/149/2/1$3 / / 1$.

${ }^{6}$ We find the same quote in Fynes Moryson's travel account in Lytton Sells (1964, p. 154).

${ }^{7}$ This ancient tradition still takes place and all the Genoese confraternities participate. According to Black (2003, pp. 39-40), one of the reasons tourists chose certain routes was the wish to attend to specific religious ceremonies around Easter.

${ }^{8}$ Hortus Siccus Rayanus, voll. 9, Sloane Collection, Natural History Museum - London (from now on NHML).

${ }^{9}$ NUL (Mi LM 17-21). Mary A. Welch gives us a detailed description of all the materials held at the Manuscripts and Special Collection, NUL (Welch, 1972) and so does C. Preston in the Appendix in Greengrass et al. (2016), discussing in detail the plant specimens in the Middleton Collection (NUL). The cited documents are: birds drawings and engravings (Mi LM 24), fishes drawings, paintings and engravings (Mi LM 25), a collection of different kind of botanical iconographies later made into a volume (Mi LM 22), a volume of dried specimens from the Padua Botanical Garden (Mi LM 23) and the dried specimens collected both in Great Britain and during the European Travel at least by Francis Willughby, John Ray, Philip Skippon but also from other hands (Mi LM 17-21).

${ }^{10}$ The Hortus Siccus Rayanus is first described by Trimen (1870), pp. $82-84$ and Dandy (1958), pp. 189-190. Ray's herbarium which after Ray's death went to his friend Samuel Dale in Essex, and then to the Chelsea Physic Garden, on to the British Museum and finally the Sloane Collection at the Natural History Museum today.

${ }^{11}$ See Dandy (1958), p. 190 where he says that the mutilation of the sheets is explained in Kalm's Account of his Visit to England: Kalm saw the collection in 1748 at the Chelsea Physic Garden and he states that Dr Sherard borrowed the collection from Samuel Dale, cutting out any rare or interesting plant.

${ }^{12}$ The notebook was first discovered by Daisy Hildyard and it is first mentioned in Greengrass et al. (2016).

${ }^{13}$ Catalogvs plantarvm Horti Patavini. Nouo incremento locupletior. GEORGIO A. TVURRE. Eiusdem Horti Praefecto Et Rei Herbariae Professore Ordin. PATAVII. MDCLXII. Typis Pauli Frambotti. Superiorum Permissu, Padua, 1662. The book is conserved at the library of the Chelsea Physic Garden (C2/40 IL). The binding is $12.8 \times 7.0 \mathrm{~cm}$, a very small, pocket volume.

${ }^{14}$ The plant is clearly Hyoscyamus albus, as indeed Ray states in Observations. Part of the transcription, the translation and the quote are taken from Greengrass et al. (2016).

${ }^{15}$ Hortus Siccus Rayanus VI, f. K10, Sloane Collection, NHML.

${ }^{16}$ Hortus Siccus Rayanus VII, f. R1, Sloane Collection, NHML. Smilax aspera is on the same sheet with Erica ramulis termis arborescens, the same order they list the plants in the notebook and in the Observations (they found the first one on the mountains between Gavi and Voltaggio, north of Genoa).

${ }^{17}$ The same list is in Ray 1694, p. 266.

${ }^{18} \mathrm{Mi}$ I 17/1, Library Catalogue, Manuscripts and Special Collection, NUL. 
${ }^{19}$ A couple of examples from Ray's library can be found in the catalogue published for the auction (Hooke, 1708$): 6$. Casp. Bauhini Theatrum Plantarum Bas. 1658, 28. Morrisoni Historia Plantarum, Tom. II Oxon. 1680, 44. Raii Historia Plantarum, 3 vol. (Charta magna), 63. Historia botanica Bolog. 1675, 149. Theod. Thabernae Montanus De Herbis, 2 vol. Bas. 1687.

${ }^{20}$ The explanation of the initials can be found in Ray (1673), after the Catalogue of plants there is an Explicatio Nominum abbreviatorum which contains all the authors used and cited by Ray. A complete list with biographical notes is in Oswald \& Preston (2011, pp. 70-96).

${ }^{21}$ In Ray's library we find infact a Theod. Thabernae Montanus De Herbis, 2 vol. Bas. 1687.

22 The copy we consulted is held at the Biblioteca della Scuola di Scienze MFN - Sede BTM (University of Genoa) and it is decorated with botanical drawings opposite some of the plants described.

${ }^{23}$ The other plants are:

'50. Triticum loliaceum [...] Genuae in moeniis sub la Lanterna. Ann.

67. Sagina apetala [...] Genuae ubique in moeniis maritimis. Ann. P. 35

78. Hyosciamus albus [...] Genuae in moeniis maritimis, et in littore alla Foce. Ann.

178. Alyssum maritimum [...] In moeniis maritimis Genuae. Floret tota hyeme. Peren. alla Cava [added by pen]

184. Cheiranthus incanus [...] Genuae in moeniis maritimis prope la Cava. Frutex. [Matthiola incana]

187. Erodium malacoides [...] Genuae sub la Lanterna Ann. [geranium]

215. Trifolium stellatum [...] Genua sub la Lanterna, et in moeniis passim. Ann.

228. Sonchus tenerrimus [...] Genuae in moeniis praecipuemaritimis. Peren.

${ }^{24}$ For an inventory of the herbals held at the Natural History Museum in Genoa see Mariotti \& Poggi (1983).

${ }^{25}$ Apart from the plants in Table 2 it was possible to identify: Ailanthus altissima (Mill.) Swingle, Asparagus acutifolius L., Atriplex hortensis L., Calamintha nepeta (L.) Savi, Centranthus ruber (L.) DC., Crithmum maritimum L., Ficus carica L., Foeniculum vulgare L., Galium aparine L., Fraxinus ornus L., Fumaria officinalis L., Hypericum perforatum L., Glaucium flavum Crantz, Inula viscosa (L.) Aiton, Ipomoea purpurea (L.) Roth., Leopoldia comosa (L.) Parl., Malva sylvestris L., Misopates calycinum (Vent.) Rothm., Parietaria judaica L., Plantago lanceolata L., Portulaca oleracea L., Oxalis acetosella L., Rubus ulmifolius Schott, Scolimus hispanicus L.Solanum nigrum L., Sonchus sp., Vicia sativa L., Vitis vinifera L. Other works with a similar methodology (but more botanically focused) are the ones on vegetation studies in Roman archaelogical areas like Blasi \& Pignatti 1984 and Caneva 2004. For an interesting cultural interpretation of Ailanthus altissima see Patrick (2014).

\section{References}

Anon (1986). Genova nel Settecento nelle vedute di Antonio Giolfi. Verona.

Arber, A. (1912). Herbals their origin and evolution. A chapter in the History of Botany 1470-1670. Cambridge. Arvati, P. (2007). Il caso demografico ligure. In G. Assereto and M. Doria (eds), Storia della Liguria. Bari, 379-400. Balzaretti, R., Pearce, M. and Watkins, C. Ligurian landscapes: microhistory and environmental history. In Balzaretti, R., Pearce, M. and Watkins, C (Eds) Ligurian Landscapes. Studies in Archaeology, Geography and History. London, 17.

Bauhin, C. (1658). Theatri botanici sive Historiae Plantarum. Basel.

Bauhin, J. (1650). Historia Plantarum Universalis. Ebroduni.

Black, J. (2003). Italy and the Grand Tour. New Haven \& London.

Blasi, C., Pignatti, S. (1984). La vegetazione degli ambienti calpestati della città di Roma. Annali di Botanica, Studi sul territorio, 42 (2), 11-16.

Bertoloni, A. (1804). Plantae Genuenses quas annis MDCCCII - MDCCCIII observavit, et recensuit Antonius Bertoloni. M. D. Genova.

Binyon, L. (1902). Catalogue of Drawings by British Artists and Artists of foreign origin working in Great Britain, preserved in the Department of Prints and Drawings in the British Museum. London.

Boulger, G. S. Willughby, Francis (1635-1672), rev. Michael Hunter, Oxford Dictionary of National Biography, Oxford.

Caneva, G. (Ed.). (2004). Amphitheatrum Naturae. Il Colosseo: storia e ambiente letti attraverso la sua flora. Milano. Caneva, G. (Ed.). (2005). La Biologia Vegetale per I Beni Culturali. Vol II. Conoscenza e Valorizzazione. Firenze. Cevasco, R. (2007). Memoria verde. Nuovi spazi per la geografia. Reggio Emilia.

Chaney, E. (1998). The Evolution of the Grand Tour. Anglo-Italian Cultural Relations since the Renaissance. London. Chaney, E., Wilks, T. (2014). The Jacobean Grand Tour. Early Stuart Travellers in Europe. London. Chard, C. (1999). Pleasure and Guilt on the Grand Tour. Travel writing and imaginative geography 1600-1830. Manchester.

Dandy, J.E. (Rev. and Ed.). (1958). The Sloane Herbarium. An annotated list of the Horti Sicci composing it; with biographical accounts of the principal contributors. Based on records compiled by the late James Britten with an introduction by Spencer Savage. London.

De Beer, E.S. (Ed.). (1959). The diary of John Evelyn. London. 
Della Torre, G. (1662). Catalogvs plantarvm Horti Patavini. Nouo incremento locupletior. GEORGIO A. TVURRE. Eiusdem Horti Praefecto Et Rei Herbariae Professore Ordin. PATAVII. MDCLXII. Typis Pauli Frambotti. Superiorum Permissu. Padova.

De Notaris, G. (1844). Repertorium Florae Ligusticae. Torino.

Dubbini, R. (2002). Geography of the Gaze. Urban and Rural Vision in Early Modern Europe. Chicago.

Elliott, P., Watkins, C. and Daniels, S. (2011). The British Arboreteum. Trees, Science and Culture in the Nineteenth Century. London.

Francis, R.A.(2011). Wall ecology: a frontier for urban biodiversity and ecological engineering. Progress in PhysicalGeography (35) 43-63.

Galassi, M.C. (2014). Topography and Mythological Transfiguration in Two Sixteenth-Century Flemish Cityscapes of Genoa: a Painting by Jan Massys and an Etching by Anton Van Den Wyngaerde. In K. Lichtert, J. Dumolyn \& M.P.J. Martens (Eds.), Portraits of the City: Representing Urban Space in Later Medieval and Early Modern Europe.

Turnhout (Studies in European Urban History, 31), 131-142.

Gerarde, J. (1636). The Herball or Generall Historie of Plantes. Gathered by John Gerarde of London Master in Chirurgerie. London.

Greengrass, M., Hildyard, D., Preston, C.D., \& Smith, P.J. (2016). Science on the Move: Francis Willughby's Expeditions. In T.R. Birkhead (Ed.), Virtuoso by nature: the scientific worlds of Francis Willughby FRS (1635-1672). Leiden.

Ginzburg, C. (1993). Microhistory: Two or Three Things That I Know About It. Critical Inquiry, 20 (1), 10-35.

Grove, A.T., Rackham, O. (2003). The Nature of Mediterranean Europe: An Ecological History. Yale University Press. Head, Lesley, Atchison, Jennifer, Phillips, Catherine and Buckingham, Kathleen (2014) Vegetal politics: belonging, practices and places. Social and Cultural Geography, 15 (8), 861-870.

Hooke, J. (1708). Bibliotheca Rayana: or, a catalogue of the library of Mr. John Ray, Late Fellow of the Royal Society. Consisting of very valuable Greek, Latin, French, English, \&c. books in Divinity, Physick, Philosophy, Philology, History, \&c. in all volumes, and of the most celebrated editions of Aldus, Stephanus, Elziver, \&c. several on large paper, gilt back, \&c. Which will be sold by auction, at the Black-Boy (alias latin) coffe-house in Ave-Mary lane, near Ludgate-street, on Thursday the 11th of this instant March [...] by Thomas Ballard, Bookseller. London.

Hunter, M. (2014). John Ray in Italy: lost manuscripts rediscovered. Notes \& Records. The Royal Society Journal of the History of Science, 1-17.

Ives, C.D., Kelly, A.H. (2015). The coexistence of amenity and biodiversity in urban landscapes. Landscape Research, $1-15$.

Jarvis, C. (2007). Order out of Chaos. Linnaean Plant Names and their Types. London.

Lassels, R. (1670). Voyage of Italy, or a Compleat Journey through Italy. In Two Parts. With the Characters of the People, and the Description of the Chief Towns, Churches, Monasteries, Tombs, Libraries, Palaces, Villas, Gardens, Pictures, Statues, and Antiquities. As Also of the Interest, Government, Riches, Force, etc of all the Princes. With Instructions concerning Travel. London.

Lytton Sells, A. (1964). The Paradise of Travellers. The Italian influence on Englishmen in Seventeenth century. London.

Mandelbrote, Scott (2004) Ray, John (1627-1705), Oxford Dictionary of National Biography, Oxford .

Mariotti, M., Poggi, R. (1983). Contributo alla conoscenza degli erbari del Museo Civico di Storia Naturale "Giacomo Doria" di Genova. In L. Capocaccia \& G. Arbocco (Ed.), Annali del Museo Civico di Storia Naturale "Giacomo Doria”, Vol. 84. Genova.

Moreno, D. (1990). Dal documento al terreno. Storia e archeologia dei sistemi agro-silvo-pastorali. Bologna.

Oswald, P.H., Preston (Transl. and eds.) (2011). John Ray's Cambridge Catalogue (1660). London.

Papone, E., Serra, A. (2011). En Plein Air. Luigi Garibbo e il vedutismo tra Genova e Firenze. Milano.

Parkinson, J. (1640). Theatrum Botanicum: the Theater of Plants. Or, an Herball of a Large Extent. London.

Patrick, D. J. (2014) The matter of displacement: A queer urban ecology of New York City's High Line. Social and Cultural Geography, 15, 920-941.

Pellegrini, P. and Baudry, S. (2014) Streets as new places to bring together both humans and plants: examples from Paris and Montpelier (France). Social and Cultural Geography, 15 (8), 871-900.

Pesce, G., Piaggio, G., Acerbo, P., Bodrato, L., Medicina, C. (2015). Comune di Genova. Notiziario Statistico, anno XXXXIII. Genova.

Petermann, G.L. (1840). In Codicem botanicum Linnaeanum Index Alphabeticus generum, specierum ac synonymorum omnium completissimus. Leipzig.

Piana, P., Balzaretti, R., Moreno, D., \& Watkins, C. (2012). Topographical art and landscape history: Elizabeth

Fanshawe (1779-1856) in early nineteenth-century Liguria. Landscape History, 33 (2), 65-81.

Pignatti, S. (1982). La Flora d'Italia, 3 vols. Bologna.

Poleggi, E. (1976). Iconografia di Genova e delle Riviere. Genova.

Poleggi, E., Cevini, P. (1981). Le città nella storia d'Italia. Genova. Roma-Bari.

Poleggi, E. (1982). Paesaggio e immagine di Genova. Genova.

Praga, C. (1998). La Lanterna: faro di Genova. Genova. 
Rackham, O. (2011). Foreword. In P.H. Oswald \& C.D. Preston (Transl. and eds.), John Ray's Cambridge Catalogue (1660) (p. vii). London.

Raggio, O. (2013). Microstoria e microstorie. In G. Galasso (Ed.), Il contributo italiano alla storia del pensiero. Storia e politica, Roma, 806-811.

Ray, J. (1673). Observations Topographical, Moral, \& Physiological Made in a Journey Through part of the LowCountries, Germany, Italy, and France: with A Catalogue of Plants not Native of England, found Spontaneously growing in those Parts, and their Virtues. London.

Ray, J. (1686). Historia Plantarum, Vol. I. London.

Ray, J. (1688). Historia Plantarum, Vol. II. London.

Ray, J. (1694). Stirpium Europaearum Extra Britannias Nascentium Sylloge. London.

Ray, J. (1704). Historia Plantarum, Vol III. London.

Richter, H.E. F. (1840). Caroli Linnaei Systema, genera, species plantarum uno volumine. Editio critica, adstricta, conferta, sive, Codex botanicus linnaeanus \&c. Leipzig.

Scotto, F. (1615). Itinerario d'Italia. Vicenza.

Scotto, F. (1659). Itinerario d'Italia. Padova.

Skippon, P. (1732). An account of a journey made thro' part of the Low-Countries, Germany, Italy and France. In A collection of voyages and travels, some now printed from original manuscripts, others now first published in English [...]. Volume VI. London.

Stoye, J. (1989). English Travellers Abroad 1604-1667 (revised edition). New Haven and London.

Sweet, R. (2012). Cities and the Grand Tour. The British in Italy, c. 1690-1820. Cambridge.

Tabernaemontanus, J.T. (1590). Eicones plantarum seu stirpium [...]. Frankfurt.

Trimen, H. (1870). Notes on Ray's 'Hortus Siccus'. Journal of Botany, British and Foreign, 8, 82-4.

Unt, A.-L., Travlou, P. \& Bell, S. (2014). Blank Space: Exploring the Sublime Qualities of Urban Wilderness at the Former Fishing Harbour in Tallinn, Estonia. Landscape Research, 39, 267-286.

Welch, M.A. (1972). Francis Willoughby, F.R.S. (1635-1672). Journal of the Society for the Bibliography of Natural History, 6, 71-85.

\section{Captions}

Figure 1 View of Genoa in F. Scoto Itinerario d'Italia (Padua, 1659) () R. Bruzzone.

Figure 2 Sketch of the area around the Lighthouse related to the construction of the new dry dock in the new pier dated 26 June 1699, Padri del Comune, filza 231-96. (C) Archivio Storico del Comune di Genova.

Figure 3 “The Lighthouse at Genoa. 1754”, George Keate (1729-1797) @ Trustees of the British Museum.

Figure 4 "Veduta del porto di Genova verso la Lanterna, dai pressi di San Teodoro", Domenico Del Pino (first half of nineteenth-century) (C) Collezione Topografica e Cartografica, Genoa.

Figure 5 "Veduta del sobborgo di Sampiardarena al ponente della città di Genova presa dallo scoglio della Lanterna", Luigi Garibbo (1812-14) @ Collezione Topografica e Cartografica, Genoa.

Figure 6 Herba Paris, Hortus Siccus Rayanus, Sloane Collection ( Natural History Museum, London.

Figure 7 178. Alyssum maritimum [...] In moeniis maritimis Genuae. Floret tota hyeme. Peren. alla Cava $($ ) Biblioteca della Scuola di Scienze MFN - Sede BTM, University of Genoa.

Figure 8 Matthiola incana (L.) R. Br., 'Flora Liguriae exsicata. N. Esposto. Cheiranthus incanus. Lin. Genuae in moeniis maritimis prope la Cava species sponte nascitur majo.9.1902. Esposto Nicolò' ( ) Museo Civico di Storia Naturale "Giacomo Doria", Genoa.

Table 1 - Data from herbals held at the Natural History Museum "G. Doria" in Genoa and at the Botanical Garden (University of Genoa) regarding the plant, the place of collection, the date, the herbal and the collection. MCSNGDGe: Museo Civico di Storia Naturale "G. Doria" Genova; PBHUGe: Polo Botanico Hanbury, Università di Genova. 
Table 2 - Plants around the Lanterna with different correspondences: the ones from the list in the notebook at the Chelsea Physic Garden (Ms CPG), in the printed volume (Observations), the Linnaean name and their presence/absence around the Lighthouse today (2014-2015).

Figure 9 Matthiola incana L. (purple flower) and Lobularia maritima (L.) Desv. (white flower) on the West side walls of the promenade facing Genoa, below the Lanterna, June 2015 (c) R. Bruzzone.

Table 1 - Data from herbals held at the Natural History Museum "G. Doria" in Genoa and at the Botanical Garden (University of Genoa) regarding the plant, the place of collection, the date of collection, the herbal and the collection. MCSNGDGe: Museo Civico di Storia Naturale "G. Doria" Genova; PBHUGe: Polo Botanico Hanbury, Università di Genova.

\begin{tabular}{|c|c|c|c|c|c|}
\hline Plant name & $\begin{array}{l}\text { Common } \\
\text { name }\end{array}$ & Place & Date & Herbal & Collection \\
\hline Hyoscyamus albus L. & $\begin{array}{l}\text { White } \\
\text { henbane }\end{array}$ & $\begin{array}{l}\text { 'Rocce litorali } \\
\text { presso la Cava a } \\
\text { Genova' }\end{array}$ & March 1894 & $\begin{array}{l}\text { Sestri } \\
\text { Ponente }\end{array}$ & $\begin{array}{l}\text { MCSNGD } \\
\text { Ge }\end{array}$ \\
\hline $\begin{array}{l}\text { Lobularia maritima (L.) } \\
\text { Desv. }\end{array}$ & $\begin{array}{l}\text { Sweet } \\
\text { alyssum }\end{array}$ & 'Cava [Genova]' & Undated & Baglietto & $\begin{array}{l}\text { MCSNGD } \\
\text { Ge }\end{array}$ \\
\hline $\begin{array}{l}\text { Lobularia maritima (L.) } \\
\text { Desv. }\end{array}$ & $\begin{array}{l}\text { Sweet } \\
\text { alyssum }\end{array}$ & $\begin{array}{l}\text { 'Genova sotto le } \\
\text { mura della Cava' }\end{array}$ & $\begin{array}{l}17 \text { March } \\
1902\end{array}$ & Esposto & $\begin{array}{l}\text { MCSNGD } \\
\text { Ge }\end{array}$ \\
\hline $\begin{array}{l}\text { Lobularia maritima (L.) } \\
\text { Desv. }\end{array}$ & $\begin{array}{l}\text { Sweet } \\
\text { alyssum }\end{array}$ & $\begin{array}{l}\text { 'Genova, presso la } \\
\text { Galleria S. } \\
\text { Benigno' }\end{array}$ & $\begin{array}{l}20 \text { April } \\
1948\end{array}$ & Mazzantini & $\begin{array}{l}\text { MCSNGD } \\
\text { Ge }\end{array}$ \\
\hline $\begin{array}{l}\text { Lobularia maritima (L.) } \\
\text { Desv. }\end{array}$ & $\begin{array}{l}\text { Sweet } \\
\text { alyssum }\end{array}$ & 'Vulg: in Liguria' & Undated & Durazzo & $\begin{array}{l}\text { MCSNGD } \\
\text { Ge }\end{array}$ \\
\hline $\begin{array}{l}\text { Matthiola incana (L.) } \\
\text { R.Br }\end{array}$ & Stock & 'Genova alla Cava' & May 1840 & Brignole & $\begin{array}{l}\text { MCSNGD } \\
\text { Ge }\end{array}$ \\
\hline $\begin{array}{l}\text { Matthiola incana (L.) } \\
\text { R.Br. }\end{array}$ & Stock & $\begin{array}{l}\text { 'Genuae in moeniis } \\
\text { maritimis prope la } \\
\text { Cava' }\end{array}$ & 9 May 1902 & Esposto & $\begin{array}{l}\text { MCSNGD } \\
\text { Ge }\end{array}$ \\
\hline $\begin{array}{l}\text { Matthiola incana (L.) } \\
\text { R.Br. }\end{array}$ & Stock & $\begin{array}{l}\text { 'Rupi marittime } \\
\text { alla Cava } \\
\text { [Genova]' }\end{array}$ & March 1894 & $\begin{array}{l}\text { Sestri } \\
\text { Ponente }\end{array}$ & $\begin{array}{l}\text { MCSNGD } \\
\text { Ge }\end{array}$ \\
\hline $\begin{array}{l}\text { Matthiola incana (L.) } \\
\text { R.Br. }\end{array}$ & Stock & $\begin{array}{l}\text { 'Alla Cava } \\
\text { Genova' }\end{array}$ & Undated & $\begin{array}{l}\text { Botanical } \\
\text { Garden }\end{array}$ & PBHUGe \\
\hline Psoralea bituminosa $\mathrm{L}$. & $\begin{array}{l}\text { Pitch } \\
\text { trefoil }\end{array}$ & $\begin{array}{l}\text { 'Prati fuori Porta } \\
\text { degli Angeli' }\end{array}$ & 12 May 1894 & $\begin{array}{l}\text { Sestri } \\
\text { Ponente }\end{array}$ & $\begin{array}{l}\text { MCSNGD } \\
\text { Ge }\end{array}$ \\
\hline Cineraria maritima $\mathrm{L}$. & $\begin{array}{l}\text { Silver } \\
\text { ragwort }\end{array}$ & 'Genua alla Cava' & Undated & Baglietto & $\begin{array}{l}\text { MCSNGD } \\
\text { Ge }\end{array}$ \\
\hline Cineraria maritima $\mathrm{L}$. & $\begin{array}{l}\text { Silver } \\
\text { ragwort }\end{array}$ & $\begin{array}{l}\text { 'Genova, scogli al } \\
\text { mare' }\end{array}$ & 1843 & Mazzini & $\begin{array}{l}\text { MCSNGD } \\
\text { Ge }\end{array}$ \\
\hline Cineraria maritima $\mathrm{L}$. & $\begin{array}{l}\text { Silver } \\
\text { ragwort }\end{array}$ & $\begin{array}{l}\text { 'Rocce del Tunnel } \\
\text { [Ge]' }\end{array}$ & 9 July 1894 & $\begin{array}{l}\text { Sestri } \\
\text { Ponente }\end{array}$ & $\begin{array}{l}\text { MCSNGD } \\
\text { Ge }\end{array}$ \\
\hline Cineraria maritima $\mathrm{L}$. & Silver & 'Rocce marittime al & 9 July 1894 & Sestri & MCSNGD \\
\hline
\end{tabular}




\begin{tabular}{|c|c|c|c|c|c|}
\hline Ms CPG & \multicolumn{2}{|c|}{ Observations (1673) } & $\begin{array}{l}\text { Linnaean name } \\
\text { (according to } \\
\text { Pignatti, 1982) }\end{array}$ & Common name & $\begin{array}{l}\text { Arounc } \\
\text { the } \\
\text { Lighth } \\
\text { ouse } \\
\text { (2014- } \\
\text { 2015) }\end{array}$ \\
\hline $\begin{array}{l}\text { 2. Trifolium } \\
\text { bituminosum }\end{array}$ & \multicolumn{2}{|c|}{ Trifolium bituminosum Ger. } & $\begin{array}{l}\text { Bituminaria } \\
\text { bituminosa (L.) } \\
\text { C.H.Stirt. or } \\
\text { Psoralea bituminosa } \\
\text { L. }\end{array}$ & Pitch trefoil & $\mathrm{X}$ \\
\hline $\begin{array}{l}\text { 3. Jacobea marina } \\
\text { sive cineraria }\end{array}$ & \multicolumn{2}{|c|}{ Jacobea marina Ger. } & $\begin{array}{l}\text { Jacobaea maritima } \\
\text { (L.), Pelser \& } \\
\text { Meijden or Senecio } \\
\text { cineraria DC }\end{array}$ & Silver ragwort & $\mathrm{X}$ \\
\hline $\begin{array}{l}\text { 4. Conyza } \\
\text { odorata } \\
\text { Monspiliaca }\end{array}$ & \multicolumn{2}{|c|}{$\begin{array}{l}\text { Conyza major Monspeliensis } \\
\text { odorata J.B. }\end{array}$} & $\begin{array}{l}\text { Inula viscosa (L.) } \\
\text { Aiton. }\end{array}$ & Yellow fleabane & $X$ \\
\hline 5. Alaternus $\square$ & \multicolumn{2}{|l|}{ Alaternus } & $\begin{array}{l}\text { Rhamnus alaternus } \\
\text { L. }\end{array}$ & $\begin{array}{l}\text { Italian } \\
\text { buckthorn }\end{array}$ & - \\
\hline $\begin{array}{l}\text { 6. Carduus laiteus } \\
\text { peregrinus } \square\end{array}$ & \multicolumn{2}{|c|}{ Carduus galactites J.B. } & $\begin{array}{l}\text { Galactites tomentosa } \\
\text { Moench. }\end{array}$ & $\begin{array}{l}\text { Purple milk } \\
\text { thistle }\end{array}$ & - \\
\hline $\begin{array}{l}\text { 7. Thymus } \\
\text { moscatus } \square\end{array}$ & \multicolumn{2}{|c|}{$\begin{array}{l}\text { Thymum vulgare rigidus folio } \\
\text { cinereo J.B. }\end{array}$} & Thymus vulgaris L. & Common thyme & $\mathrm{X}$ \\
\hline $\begin{array}{l}\text { 8. Geraniù } \\
\text { Althaea foliù } \square\end{array}$ & \multicolumn{2}{|c|}{ Geranium folio Althææ C.B. } & $\begin{array}{l}\text { Erodium malacoides } \\
\text { L. }\end{array}$ & $\begin{array}{l}\text { Mediterranean } \\
\text { storksbill }\end{array}$ & $\mathrm{X}$ \\
\hline $\begin{array}{l}\text { 9. Thlaspi } \\
\text { incarnù marinù } \\
\text { flo albo }\end{array}$ & \multicolumn{2}{|c|}{$\begin{array}{l}\text { Thlapsi Alysson dictum maritimum } \\
\text { C.B. }\end{array}$} & $\begin{array}{l}\text { Lobularia maritima } \\
\text { (L.) Desv. }\end{array}$ & Sweet alyssum & $\mathrm{X}$ \\
\hline $\begin{array}{l}\text { 10. Lotus an } \\
\text { Cytisus } \\
\text { villosus? } \\
\end{array}$ & \multicolumn{2}{|c|}{$\begin{array}{l}\text { Lotus Libyca Dalechampii; Lotus } \\
\text { pentaphyllos siliquosus villosus } \\
\text { C.B. }\end{array}$} & $\begin{array}{l}\text { Dorychnium } \\
\text { hirsutum } L .\end{array}$ & $\begin{array}{l}\text { Hairy canary } \\
\text { clover }\end{array}$ & - \\
\hline $\begin{array}{l}\text { 11. Dorycniù } \\
\text { Monsplelions }\end{array}$ & \multicolumn{2}{|l|}{-} & $\begin{array}{l}\text { Dorychnium } \\
\text { hirsutum } \mathrm{L} .\end{array}$ & $\begin{array}{l}\text { Hairy canary } \\
\text { clover }\end{array}$ & - \\
\hline $\begin{array}{l}\text { 12. Smilax } \\
\text { aspera } \square\end{array}$ & \multicolumn{2}{|l|}{ Smilax aspera } & Smilax aspera $\mathrm{L}$. & Common smilax & $\mathrm{X}$ \\
\hline $\begin{array}{l}\text { 13. Genista } \\
\text { Hispanica }\end{array}$ & \multicolumn{2}{|l|}{-} & Genista hispanica L. & Spanish broom & - \\
\hline $\begin{array}{l}\text { 14. Adianthum } \\
\text { nigrum } \square\end{array}$ & $\begin{array}{l}\text { Adianthum sive C } \\
\text { J.B. }\end{array}$ & jillus veneris & $\begin{array}{l}\text { Adiantum capillus- } \\
\text { veneris } \mathrm{L} \text {. }\end{array}$ & $\begin{array}{l}\text { Southern } \\
\text { maidenhair fern }\end{array}$ & - \\
\hline 15. Hyosciamus 2 & Hyosciamus albus & ark. & Hyoscyamus albus $\mathrm{L}$. & White henbane & $\mathrm{X}$ \\
\hline & Stock-July- flowe & & $\begin{array}{l}\text { Matthiola incana } \\
\text { (L.) R. Br. }\end{array}$ & Stock & $\mathrm{X}$ \\
\hline & ragwort & 'Tunnel (Genova)' & & ente & \\
\hline Thymus vulgaris $\mathrm{L}$. & $\begin{array}{l}\text { Common } \\
\text { thyme }\end{array}$ & $\begin{array}{l}\text { 'Terrapieni fuori } \\
\text { Porta Angeli' }\end{array}$ & 1 June 1862 & $\begin{array}{l}\mathrm{MC} \\
\mathrm{Ge}\end{array}$ & \\
\hline
\end{tabular}

Table 2 - Plants around the Lanterna with different correspondences: the ones from the list in the notebook at the Chelsea Physic Garden (Ms CPG), in the printed volume (Observations), the Linnaean name, the common name and their presence/absence around the Lighthouse today (2014-2015). 


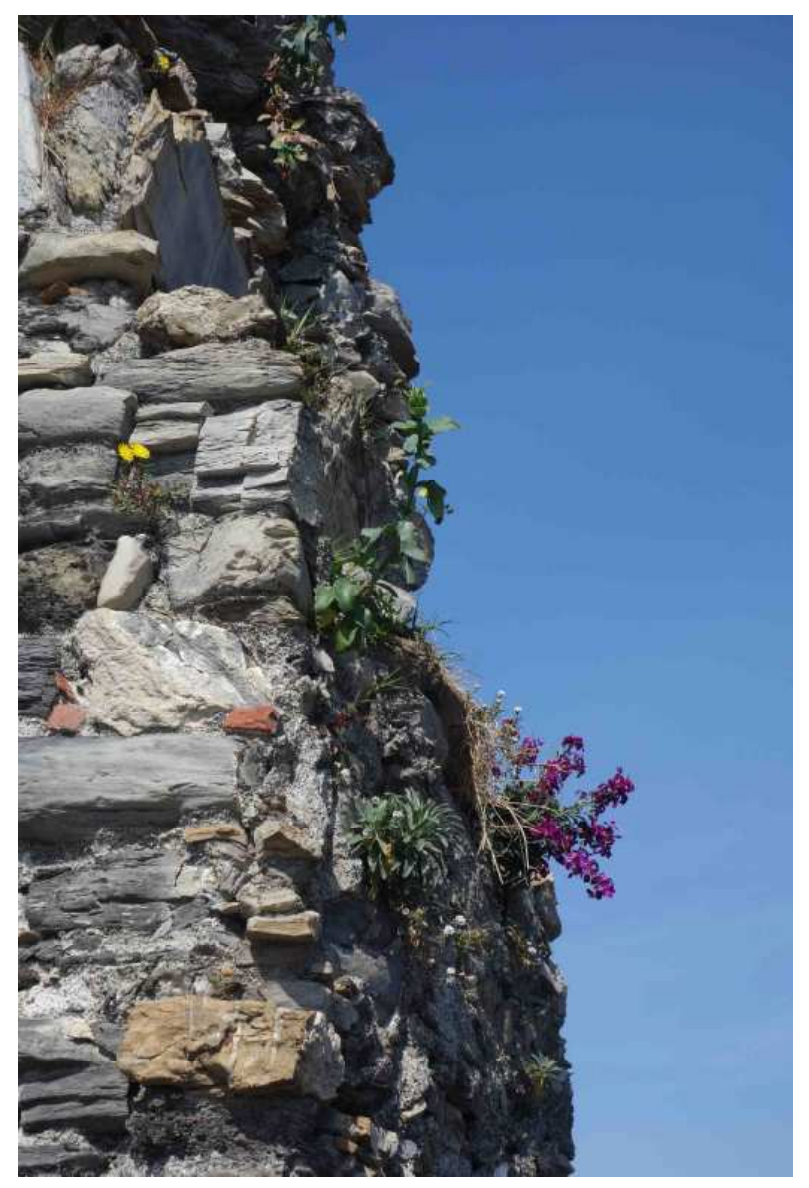

Figure 9 Matthiola incana L. (purple flower) and Lobularia maritima (L.) Desv. (white flower) on the West side walls of the promenade facing Genoa, below the Lanterna, June 2015 @ R. Bruzzone. 